\title{
Sensorial and fatty acid profile of ice cream manufactured with milk of crossbred cows fed palm oil and coconut fat
}

\author{
S. A. S. Corradini, ${ }^{*}$ G. S. Madrona, ${ }^{* 1}$ J. V. Visentainer, $†$ E. G. Bonafe, $†$ C. B. Carvalho, ${ }^{*}$ P. M. Roche, $\ddagger$ \\ and I. N. Prado§ \\ ${ }^{*}$ Agricultural Science Center, and \\ †Department of Chemistry, State University of Maringá (UEM), Colombo Avenue, 5790, Maringá, Paraná, 87020-900, Brazil \\ ‡Department of Nursing, State University of Ponta Grossa, Avenue Gal Carlos Cavalcanti, 4748, Ponta Grossa, Paraná, 84030-900, Brazil \\ §Department of Animal Science, State University of Maringá, fellowship IA of Conselho Nacional de Desenvolvimento Científico e Tecnológico \\ (CNPq), Brazil, Av. Colombo, 5790, CEP, 87020-900, Maringá, Paraná, Brazil
}

\begin{abstract}
This work was carried out to study the nutritional quality of milk of cows fed palm oil (PAL) or coconut fat $(\mathrm{COC})$, and the use of that milk as raw material for ice cream production. Three treatments were tested with 23 healthy cows: control (CON), PAL, and COC. The milk was collected at d 21 and 36 of the experimental diet. Proximate composition (moisture, ash, fat, protein, and carbohydrates) and fatty acid composition were evaluated on milk and ice cream, and sensorial analysis, color (lightness, green/red, and blue/yellow), overrun, and texture were evaluated on the ice cream. Fatty acids present in milk and ice cream were determined by gas chromatography. Sensory analysis results showed that the ice cream acceptability index was above $70 \%$. No difference was observed for proximate composition in milk and ice cream. Chromatographic analysis showed an increase in saturated fatty acid concentration in CON and lower levels in PAL; polyunsaturated fatty acid concentration was higher in PAL and lower in $\mathrm{CON}$, in milk and ice cream; monounsaturated fatty acid concentration in milk was higher in PAL and lower in CON but no difference was found in ice cream. Comparing n-3 content in milk and ice cream, we observed that PAL had higher levels than CON and COC. The results indicate that it is feasible to add sources of fat to the animal feed for fatty acid composition modulation of milk and ice cream.
\end{abstract}

Key words: dairy product, conjugated linoleic acid, fatty acid, ice-cold food

\section{INTRODUCTION}

During the past few years, some technological advances have been made regarding dairy products, reflecting the diversity and quality of what is consumed

Received April 25, 2014.

Accepted July 24, 2014.

${ }^{1}$ Corresponding author: gsmadrona@uem.br today. This was attained through an FA modulation on diets offered to dairy cows. Some of these FA are beneficial to human health, which makes them important as daily dietary supplements.

In many studies, the overconsumption of high-fat foods has been linked to the increasing incidence of obesity (Cadena et al., 2012). According to Caroprese et al. (2013), dietary recommendations indicate a reduction of fat intake, in terms of saturated and trans FA, and fat of animal origin.

A healthy fat composition of milk and derivatives are required to balance a diet, due to the presence of essential FA and vitamins, usually the fat-soluble ones (Chen et al., 2004). The high percentage of short- and long-chain FA is associated with low-density lipoprotein synthesis, responsible for cardiovascular diseases (Funck et al., 2006). However, low levels of MUFA and PUFA are found in milk. Conjugated linoleic acid is an important PUFA, which, even in low concentrations, improves health functions, such as reduction of coronary disease incidence, increase in high-density lipoprotein concentration, and reduction of body fat (Arbonés-Mainar et al., 2006).

Some FA are essential to human body normal function. They are not produced in the amounts the organism needs, so they must be in the human diet. An example of such FA is monolaurin, which has antiviral properties and is found in coconut fat $(\mathbf{C O C}$; Machado et al., 2006). Palm oil (PAL) has large industrial application and is one of the major natural sources of carotenoids (Nozière et al., 2006).

The choice of ice cream is because, according to Karaman et al. (2014), this product is commonly enjoyed by people of all ages due to its cooling effect, and the nutritive value of ice cream is high, as it is a milk-based dessert. Development of new ice cream formulations that are highly enjoyed by consumers is one of the driving forces of ice cream manufacturers. Ice cream is a great energy source, of which the content is almost totally assimilated (Marshall et al., 2003). 
Many authors have developed and evaluated ice cream (Cadena et al., 2012; Ferraz et al., 2012; Harwood et al., 2013; Karaman et al., 2014); however, little information exists about FA profile modification and its influence in final product acceptance. An ideal ice cream should correspond to the trust limits concerning quality criteria for taste, body, texture, melting characteristics, color, packing, microbial content, and composition (Marshall et al., 2003).

The objective of this study was to feed a diet supplemented with PAL or COC to 23 dairy cows and obtain the milk in 2 periods (at $\mathrm{d} 21$ and 36 ), produce ice cream from the collected milk, and carry out physicochemical and sensorial analyses on the products.

\section{MATERIALS AND METHODS}

\section{Animals, Experimental Design, Dietary Treatments, Milk Sampling, and Analysis}

The experiment was realized at Marques' Farm (a commercial farm in Mirador, Paraná State, Brazil; $\left(23^{\circ} 15^{\prime} 22^{\prime \prime} \mathrm{S}, 52^{\circ} 46^{\prime} 28^{\prime \prime} \mathrm{W}\right)$ during December (summer season). Three different diets were fed to cows according to Corradini et al. (2013).

Experimental diets were fed to 23 healthy crossbred dairy cows (Holstein $\times$ Zebu) by d 60 of their third lactation. Cows were milked daily and were randomly distributed in 3 groups of 3 isoenergetic diets: control (CON; 8 cows), PAL (8 cows) and COC (7 cows). Concentrate was offered to the cows once per day after milking, and then cows remained in pasture (Brachiaria decumbens). The first milk sampling was carried out at d 21 (period 1) and the second at d 36 after the beginning of the experiment (period 2).

The physicochemical analyses (moisture, fat, protein, ash, lactose, acidity, and total dry extract) of milk were conducted in an Ekomilk Ultrasonic Milk Analyzer (Ekomilk total; Eon Trading Inc., Haskovska, Bulgaria). Milk samples were analyzed at the Milk Clinic in Piracicaba (São Paulo, Brazil), where total bacteria count (TBC) and SCC were set with a bacteria counter with flow cytometry. Milk samples that did not meet the specifications of Regulation 62 (MAPA, 2011) were ruled out. The collected milk was transported in stainless steel receptacles under refrigeration to the State University of Paraná (UEM; Maringá, Paraná, Brazil), where the ice cream was immediately processed.

\section{Ice Cream Manufacture}

The ice cream was produced separately by treatment, by sampling day and by cow: 23 ice creams for the first collection (d 21) and 23 ice creams for the second collection (d 36). This procedure was carried out in the Food Engineering Milk and Derivatives Laboratory at the State University of Maringá (UEM). The ice cream was composed of $1.48 \%$ base powder, $74.07 \%$ milk, $19.52 \%$ sugar, $4.44 \%$ fat, and $0.49 \%$ stabilizer. After each process, the equipment was washed and sanitized. After processing, samples were identified and stored at a temperature of $-18^{\circ} \mathrm{C}$.

\section{Ice Cream Physicochemical Analysis, Overrun, and Microbial Analysis}

Centesimal composition analyses were made of moisture, protein, and ash (AOAC International, 1998), fat (Bligh and Dyer, 1959), and carbohydrates by difference. The physicochemical analyses were carried out right after production at the Food Engineering Laboratory at the State University of Maringa (UEM). All determinations were made in duplicate. The volumes for mixture samples and final aerated products were measured to set the overrun calculated according to Silva Junior and Lannes (2011).

Samples were microbiologically evaluated in duplicate. Samples were randomly separated (between 2 periods) and, at this stage, the same samples were used for sensorial analysis. The presence of thermotolerant coliforms, coagulase-positive Staphylococcus spp., and Salmonella spp. were investigated according to Regulation 62 (MAPA, 2011).

\section{Color and Texture Analysis}

Color was evaluated through a portable colorimeter (Minolta CR10; with an integrating sphere and viewing angle of $3^{\circ}$, D3 lighting, and illuminant D65; Konica Minolta Business Solutions do Brasil Ltda., Manaus, Amazonas, Brazil). The system used was the International Commission on Illumination (CIE) $\mathrm{L}^{*} \mathrm{a} \mathrm{b}^{*}$ system, where $\mathbf{L}^{*}$ represents luminosity on a scale from 0 (black) to 100 (white), $\mathbf{a}^{*}$ represents a tone scale varying from red (positive values) to green (negative values), and $\mathbf{b}^{*}$ represents a scale from yellow (positive values) to blue (negative values). Color saturation rate $\left(\mathbf{C}^{*}\right)$ and tone angle $\left(\mathbf{H}^{*}\right)$ were obtained according to Sousa et al. (2003). All determinations were made in duplicate.

Texture analysis was carried out in a Stable Micro Systems TA.XTplus Texture Analyzer (Texture Technologies Corp., Godalming, UK) in triplicate. According to Silva and Bolini (2006), the testing characteristics were as follows: accessory probe: $36 \mathrm{~mm}$, mode: strength measured in compression, pretest speed: 2.0 $\mathrm{mm} / \mathrm{s}$, test speed: $3.0 \mathrm{~mm} / \mathrm{s}$, posttest speed: $7.0 \mathrm{~mm} / \mathrm{s}$, and distance: $10 \mathrm{~mm}$. 


\section{Consumer Test}

According to results from milk characterization, samples that present high SCC and TBC were disregarded; thus, 2 samples of ice cream from each treatment were randomly selected at both production stages. The analysis was carried out at the Sensorial Analysis Laboratory at State University of Maringá (UEM), with approval by the UEM Ethics Committee (number 703/2011 e CAAE: 0415.0.093.000-11).

The acceptance test was applied using a 9-point hedonic scale, from 1 = highly disliked it to $9=$ highly liked it (Pimentel et al., 2013; Morais et al., 2014). The formulations were evaluated considering the attributes of color, smell, texture, and taste using a team of 50 potential consumers of the products (untrained), randomly selected. The samples were stored $24 \mathrm{~h}$ at $-18^{\circ} \mathrm{C}$ and removed from the freezer and tempered for 5 min at $20^{\circ} \mathrm{C}$ before sensory analysis (Di Criscio et al., 2010). Ice cream samples of almost $20 \mathrm{~g}$ were offered to the consumers in a monadic presentation, on disposable white plastic containers codified with 3 -digit random numbers. The consumers received a glass of water to be consumed between samples (Meilgaard et al., 1991). The acceptability index was performed according to the overall acceptance attribute (Stone and Sidel, 1985; Corradini et al., 2013). The product's acceptability index was calculated using the following equation:

$$
\text { Acceptability index }(\%)=\mathrm{A} \times 100 / \mathrm{B} \text {, }
$$

where $\mathrm{A}=$ average score for the product and $\mathrm{B}=$ maximum score given to the product.

\section{Chromatographic Analyses}

Triacylglycerol transesterification was carried out to obtain methyl esters of FA, according to the method of the International Organization for Standardization (ISO, 1978). The esters of FA were separated in a Thermogas chromatograph (model trace ultra 3300; Thermo Scientific, Wilmington, DE), equipped with a flameionization detector and fused-silica capillary column [CP-7420; $100 \mathrm{~m} \times 0.25 \mathrm{~mm}$ i.d., $0.25-\mu \mathrm{m}$ film thickness; the gas flow rates used were $1.2 \mathrm{~mL} / \mathrm{min}$ (with $\mathrm{H}_{2}$ as the carrier gas), $30 \mathrm{~mL} / \mathrm{min}$ for the make-up gas $\left(\mathrm{N}_{2}\right)$, and 35 and $300 \mathrm{~mL} / \mathrm{min}$ for the flame gases $\left(\mathrm{H}_{2}\right.$ and synthetic air, respectively)]. The volume injected was $2.0 \mu \mathrm{L}$, using a sample division of 1:80, with injector and detector temperatures of 220 and $230^{\circ} \mathrm{C}$, respectively, and a column temperature of $65^{\circ} \mathrm{C}$ for $4 \mathrm{~min}$, which was increased to $185^{\circ} \mathrm{C}$ at a rate of $4^{\circ} \mathrm{C} / \mathrm{min}$ and held for $0.75 \mathrm{~min}$. The percentage was set through the integration of peak areas by Chronquest software (version 5.0; Thermo Fisher Scientific Inc., Waltham, MA).

\section{Statistical Analysis}

Statistical data analysis was carried out using ANOVA and average calculus by Bonferroni test at a $5 \%$ significance level through Statistics 7.0 software (Vince Stat Software). First, each parameter was compared for the different samples and second, each parameter was compared in 2 different periods (period 1 and period 2; Corradini et al., 2013).

\section{RESULTS AND DISCUSSION}

\section{Milk Characterization}

Table 1 presents the results from TBC and SCC of milk collected from 23 cows in 2 collection periods and the physicochemical results. We observed that most in natura milk samples evaluated were in accordance with the current legislation both for TBC and SCC $(6.0 \times$ $10^{5}$ cells $/ \mathrm{mL}$ ). Milk samples that were found to be out of compliance with Regulation 62 (MAPA, 2011) were ruled out.

In a study by Machado et al. (2000), 920 milk samples from tanks in herds from São Paulo and Minas Gerais (Brazil) were analyzed and no difference was found for TS related to scores of SCC varying from $12 \times 10^{5}$ to $3.2 \times 10^{5}$ cells $/ \mathrm{mL}$. The same study presented an increased fat level (3.58 to $4.15 \%$ ) in milk from cows with mastitis.

When milk composition was analyzed, only lactose presented a significant difference; for all other milk components, no significant difference was detected (Table 1) and they were in accordance with Regulation 62 in Brazil (MAPA, 2011), which requires a minimum of $3 \%$ fat, acidity of 0.14 to 0.18 ( $\mathrm{g}$ of lactic acid/100 $\mathrm{mL}), 8.4 \%$ fat-free dry extract, and $2.9 \%$ protein.

The lactose level in milk from cows fed PAL was lower $(P<0.05)$ in the first collection period, which did not occur according to the results from the second period. This can be explained, because according to Fonseca (2000), the composition of milk involves the effects of feeding, reproductive management, genetic heritage, and other factors.

\section{Chromatographic Analysis of In Natura Milk}

The FA composition of in natura milks is presented in Table 2. The major FA found were palmitic (16:0), vaccenic (18:1n-7), stearic (18:0), myristic (14:0), and lauric (12:0). 
Table 1. Milk physicochemical and microbial analyses (mean \pm SD from analyses in triplicate)

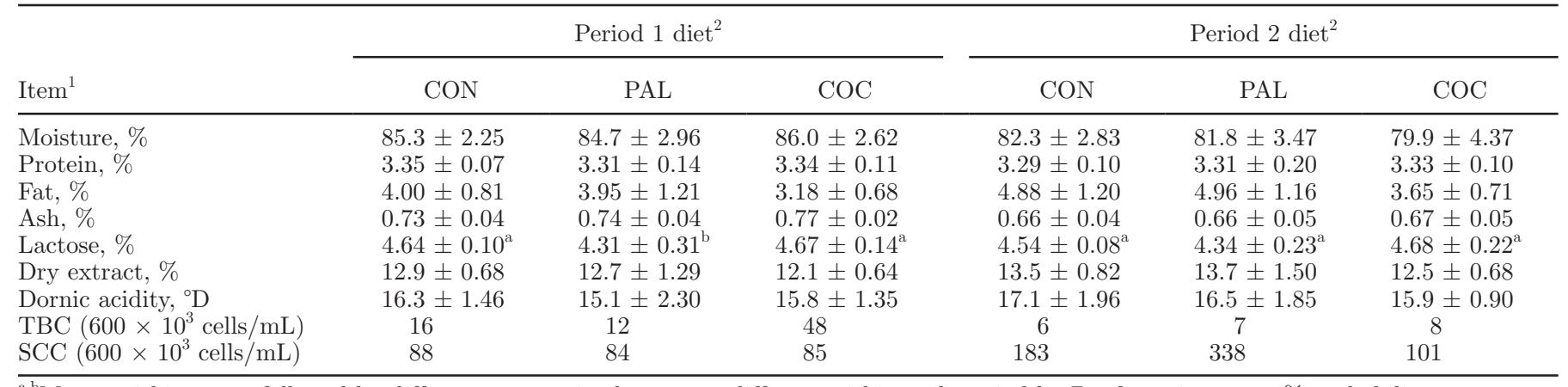

${ }^{\mathrm{a}, \mathrm{b}}$ Means within a row followed by different superscript letters are different within each period by Bonferroni test at $5 \%$ probability.

${ }^{10} \mathrm{D}=$ Dornic degrees; TBC $=$ total bacteria count.

${ }^{2} \mathrm{CON}=$ control diet; $\mathrm{PAL}=$ diet with palm oil; $\mathrm{COC}=$ diet with coconut fat.

A predominance of $\alpha$-linolenic acid (18:3n-3) was observed in both periods for the PAL treatment, from n-3 series FA; trans FA were found in the 3 treatments of both periods, in which the predominant form was elaidic acid (trans 18:1n-9). We observed a lower percentage of SFA in both periods of milk collection for cows fed PAL; thus, lower ingestion of these FA is an aspect that has been highlighted.

Milk FA composition is directly related to the material used in feeding cows. Thus, it is known that $\mathrm{COC}$ has high (43-51\%) lauric acid (12:0), which increased this FA in milk in both periods for cows fed COC. Palm oil has high (36-47\%) oleic acid (cis 18:1n-9), which increased this FA in milk in both periods for cows fed PAL. Scientific researchers have shown that lauric acid has the capacity to improve the immunological system, by unleashing a substance called interleukin, which when activated, leads the bone narrow to produce more white cells (Machado et al., 2006). Furthermore, lauric acid acts as an antiinflammatory through the inhibition of prostaglandin local synthesis (prostaglandin E2) and IL-6, proinflammatory substances present in rheumatic diseases, arthritis, and muscle inflammations (Machado et al., 2006).

Rumenic acid, another name for CLA (cis-9,trans-11 18:2), was found in both collection periods. Conjugated

Table 2. Fatty acids in milk (\% relative area; mean \pm SD from analyses in triplicate)

\begin{tabular}{|c|c|c|c|c|c|c|}
\hline \multirow[b]{2}{*}{ FA } & \multicolumn{3}{|c|}{ Period 1 diet $^{1}$} & \multicolumn{3}{|c|}{ Period 2 diet $^{1}$} \\
\hline & $\mathrm{CON}$ & PAL & $\mathrm{COC}$ & $\mathrm{CON}$ & PAL & $\mathrm{COC}$ \\
\hline $12: 0$ & $3.52 \pm 1.23^{\mathrm{a}}$ & $2.28 \pm 0.40^{\mathrm{b}}$ & $4.85 \pm 0.81^{\mathrm{c}}$ & $3.36 \pm 0.77^{\mathrm{A}}$ & $2.23 \pm 0.46^{\mathrm{B}}$ & $4.38 \pm 0.57^{\mathrm{C}}$ \\
\hline $14: 0$ & $12.27 \pm 1.88^{\mathrm{a}}$ & $10.27 \pm 1.09^{\mathrm{b}}$ & $13.51 \pm 1.30^{\mathrm{a}}$ & $11.66 \pm 0.83^{\mathrm{A}}$ & $10.14 \pm 0.77^{\mathrm{B}}$ & $12.68 \pm 1.37^{\mathrm{A}}$ \\
\hline $16: 0$ & $38.95 \pm 3.33^{\mathrm{a}}$ & $35.54 \pm 2.67^{\mathrm{ab}}$ & $33.73 \pm 1.95^{\mathrm{b}}$ & $35.25 \pm 3.87^{\mathrm{A}}$ & $34.59 \pm 2.21^{\mathrm{A}}$ & $33.63 \pm 2.90^{\mathrm{A}}$ \\
\hline $18: 0$ & $13.54 \pm 3.34^{\mathrm{a}}$ & $13.30 \pm 2.99^{\mathrm{a}}$ & $13.13 \pm 3.03^{\mathrm{a}}$ & $13.28 \pm 0.99^{\mathrm{A}}$ & $13.35 \pm 2.94^{\mathrm{A}}$ & $13.19 \pm 2.94^{\mathrm{A}}$ \\
\hline trans $18: 1 \mathrm{n}-9$ & $0.52 \pm 0.24^{\mathrm{a}}$ & $0.78 \pm 0.14^{\mathrm{b}}$ & $0.51 \pm 0.11^{\mathrm{a}}$ & $0.44 \pm 0.07^{\mathrm{A}}$ & $0.71 \pm 0.10^{\mathrm{B}}$ & $0.49 \pm 0.08^{\mathrm{A}}$ \\
\hline cis $18: 1 n-9$ & $2.62 \pm 0.26^{\mathrm{a}}$ & $2.88 \pm 0.39^{\mathrm{ab}}$ & $2.25 \pm 0.39^{\mathrm{ac}}$ & $2.84 \pm 0.59^{\mathrm{A}}$ & $3.04 \pm 0.40^{\mathrm{AB}}$ & $2.40 \pm 0.25^{\mathrm{AC}}$ \\
\hline $18: 1 \mathrm{n}-7$ & $18.70 \pm 3.31^{\mathrm{a}}$ & $22.93 \pm 1.44^{\mathrm{b}}$ & $20.04 \pm 2.00^{\mathrm{ab}}$ & $20.31 \pm 2.74^{\mathrm{A}}$ & $23.75 \pm 1.26^{\mathrm{B}}$ & $21.17 \pm 2.78^{\mathrm{AB}}$ \\
\hline $18: 3 n-3$ & $0.85 \pm 0.17^{\mathrm{a}}$ & $1.07 \pm 0.18^{\mathrm{ab}}$ & $0.75 \pm 0.18^{\mathrm{ac}}$ & $0.99 \pm 0.20^{\mathrm{A}}$ & $1.03 \pm 0.43^{\mathrm{A}}$ & $0.86 \pm 0.30^{\mathrm{A}}$ \\
\hline cis-9,trans-11 18:2 & $0.21 \pm 0.04$ & $0.21 \pm 0.04$ & $0.20 \pm 0.04$ & $0.20 \pm 0.01$ & $0.19 \pm 0.05$ & $0.19 \pm 0.02$ \\
\hline Others $^{2}$ & $11.3 \pm 0.14$ & $10.7 \pm 0.16$ & $11.0 \pm 0.16$ & $11.6 \pm 0.15$ & $11.0 \pm 0.16$ & $11.0 \pm 0.13$ \\
\hline SFA & $73.7 \pm 7.98^{\mathrm{a}}$ & $66.4 \pm 1.89^{\mathrm{b}}$ & $70.6 \pm 2.62^{\mathrm{ab}}$ & $69.2 \pm 2.92^{\mathrm{A}}$ & $65.5 \pm 1.82^{\mathrm{B}}$ & $68.9 \pm 3.33^{\mathrm{AB}}$ \\
\hline MUFA & $24.5 \pm 7.66^{\mathrm{a}}$ & $31.5 \pm 1.80^{\mathrm{b}}$ & $27.7 \pm 2.51^{\mathrm{ab}}$ & $28.9 \pm 2.89^{\mathrm{A}}$ & $32.5 \pm 1.49^{\mathrm{B}}$ & $29.1 \pm 3.13^{\mathrm{AB}}$ \\
\hline PUFA & $1.77 \pm 0.37^{\mathrm{a}}$ & $2.11 \pm 0.16^{\mathrm{b}}$ & $1.74 \pm 0.30^{\mathrm{a}}$ & $1.88 \pm 0.37$ & $2.05 \pm 0.56$ & $1.98 \pm 0.30$ \\
\hline$n-6$ & $0.71 \pm 0.27$ & $0.82 \pm 0.11$ & $0.80 \pm 0.24$ & $0.69 \pm 0.27$ & $0.84 \pm 0.11$ & $0.93 \pm 0.12$ \\
\hline$n-3$ & $0.85 \pm 0.17^{\mathrm{a}}$ & $1.07 \pm 0.18^{\mathrm{b}}$ & $0.75 \pm 0.18^{\mathrm{a}}$ & $0.99 \pm 0.20^{\mathrm{A}}$ & $1.03 \pm 0.43^{\mathrm{B}}$ & $0.86 \pm 0.30^{\mathrm{A}}$ \\
\hline$n-9$ & $5.75 \pm 0.42^{\mathrm{a}}$ & $6.24 \pm 0.32^{\mathrm{a}}$ & $5.06 \pm 0.39^{\mathrm{b}}$ & $5.93 \pm 0.59^{\mathrm{A}}$ & $6.37 \pm 0.36^{\mathrm{B}}$ & $5.34 \pm 0.50^{\mathrm{A}}$ \\
\hline$n-6: n-3$ & $0.84 \pm 0.31$ & $0.79 \pm 0.18$ & $1.11 \pm 0.35$ & $0.71 \pm 0.30$ & $1.24 \pm 4.18$ & $1.21 \pm 0.53$ \\
\hline PUFA:SFA & $0.03 \pm 0.15$ & $0.03 \pm 0.21$ & $0.03 \pm 0.20$ & $0.03 \pm 0.17$ & $0.03 \pm 0.12$ & $0.03 \pm 0.18$ \\
\hline
\end{tabular}

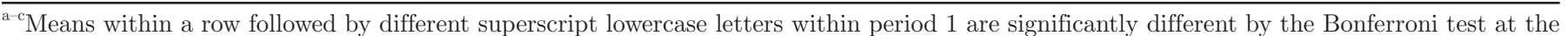
$5 \%$ probability level.

${ }^{A-C}$ Means within a row followed by different superscript uppercase letters within period 2 are significantly different by the Bonferroni test at the $5 \%$ probability level.

${ }^{1} \mathrm{CON}=$ control diet; $\mathrm{PAL}=$ diet with palm oil; $\mathrm{COC}=$ diet with coconut fat.

${ }^{2} 4: 0,6: 0,8: 0,10: 0,14: 1 n-11,14: 1 n-9,14: 1 n-7,15: 0,15: 1 n-9,16: 1 n-11,16: 1 n-9,16: 1 n-7$, iso 17:0, 17:0, 17:1n-9, trans 18:2n-6, and cis 18:2n-6. 
linoleic acid is formed in the rumen through the action of an isomerase that converts linoleic acid connections into conjugated connections. However, its main milk source is from endogenous mammary gland synthesis through vaccenic acid. Vaccenic acid (trans 18:1n-7) is an intermediate in ruminal biohydrogenation, being converted into CLA through the action of the enzyme $\Delta^{9}$-desaturase, in mammary tissues and glands. It is known that several factors affect the quantity of CLA in milk, such as the season of the year and physiological factors (Simionato et al., 2010).

\section{Ice Cream Composition and Physicochemical Parameters and Overrun}

The ice cream centesimal composition from different treatments is presented in Table 3. No significant difference for the analyzed parameters was detected, and the results obtained are according to Chiara et al. (2003), in which the approximate composition should generally be $7.46 \%$ for fat, $63.96 \%$ for moisture, $24.80 \%$ for carbohydrate, and $0.70 \%$ for ash. The results are also according to those described in Regulation 379 (ANVISA, 1999), which specify a minimum of $3 \%$ for fat and $2.5 \%$ for protein. The data found for $\mathrm{pH}$ in ice cream are according to Shaviklo et al. (2011), who evaluated the chemical properties of ice cream fortified with fish protein and had a $\mathrm{pH}$ of 6.7 for the control formulation (without adding protein).

In another study, Pereira et al. (2011) evaluated the influence of a partial replacement of milk by soy milk and found $0.94 \%$ for ash and $22.41 \%$ for carbohydrate in ice cream, which is similar to the values found in the current study. The protein content found by those authors was lower (3.99\%) and fat higher (10.15\%) compared with the values found in our work.

Ice cream is mainly constituted of carbohydrates and fat, and also contains protein, minerals, and vitamins. Ice cream composition also varies according to location and market, considering not only manufactures' opinions, but also the conditions under which they are made (Marshall et al., 2003). Comparing milk with ice cream composition, no significant difference for the analyzed parameters in ice cream is expected.

When analyzing overrun, no significant difference was detected in all treatments; many authors have studied this parameter, which is an important quality factor. Karaca et al. (2009) evaluated fat reduction in various levels for ice cream and found overrun values among 10 and $58 \%$. According to those authors, low fat quantity leads to low overrun. Di Criscio et al. (2010) produced ice cream with inulin $(0,2.5,5$, and $10 \%)$ and observed that ice creams with inulin added at 5 and $10 \%$ had overrun values of about 38.8 and $38.4 \%$, respectively, and the control sample had an overrun of $37.0 \%$; the control sample value was lower than the results found in our study.

According to Goff (2002), the air incorporation in ice cream must be between 10 and $50 \%$. Thus, our study presents overrun values in accordance to the ones in the literature. Silva and Bolini (2006) worked with ice cream with different sorts of whey from bovine milk and noted an overrun of $50 \%$ for samples with $100 \%$ milk, according to the proposed procedure.

\section{Ice Cream Microbial Analysis}

The results from ice cream microbial analysis are shown in Table 4. For the experimental diets, all samples were found to be according to the limits set by the Brazilian legislation (ANVISA, 2001). The CON diet presented higher coliforms count compared with the COC and PAL diets. It is very important to evaluate the product microbiology because great portions of commercialized ice cream are consumed by children and so it is necessary to take special care in choosing raw materials and processing (Warke et al., 2000).

\section{Ice Cream Color and Texture Analysis}

In Table 5, the average values found for $\mathrm{L}^{*}, \mathrm{a}^{*}, \mathrm{~b}^{*}$, $\mathrm{C}^{*}$, and $\mathrm{H}^{*}$ for ice cream samples in both periods are

Table 3. Results (mean \pm SD) from ice cream physicochemical analyses and overrun (from analyses in triplicate)

\begin{tabular}{|c|c|c|c|c|c|c|}
\hline \multirow[b]{2}{*}{ Item } & \multicolumn{3}{|c|}{ Period 1 diet $^{1}$} & \multicolumn{3}{|c|}{ Period 2 diet $^{1}$} \\
\hline & $\mathrm{CON}$ & PAL & $\mathrm{COC}$ & $\mathrm{CON}$ & PAL & $\mathrm{COC}$ \\
\hline Moisture, \% & $63.7 \pm 3.14$ & $64.9 \pm 2.44$ & $64.5 \pm 2.30$ & $61.8 \pm 7.3$ & $64.2 \pm 3.8$ & $63.5 \pm 4.9$ \\
\hline Protein, $\%$ & $6.51 \pm 0.50$ & $7.37 \pm 1.31$ & $6.22 \pm 0.76$ & $6.83 \pm 0.58$ & $6.69 \pm 0.99$ & $6.61 \pm 0.49$ \\
\hline Fat, $\%$ & $6.70 \pm 0.48$ & $7.05 \pm 0.56$ & $6.82 \pm 0.75$ & $6.94 \pm 0.63$ & $6.82 \pm 0.60$ & $7.05 \pm 0.75$ \\
\hline Carbohydrate, \% & $22.4 \pm 0.86$ & $19.9 \pm 0.74$ & $21.7 \pm 0.78$ & $23.9 \pm 0.5$ & $21.8 \pm 0.6$ & $22.2 \pm 0.9$ \\
\hline Ash, $\%$ & $0.71 \pm 0.02$ & $0.71 \pm 0.02$ & $0.71 \pm 0.02$ & $0.47 \pm 0.03$ & $0.48 \pm 0.05$ & $0.51 \pm 0.07$ \\
\hline $\mathrm{pH}$ & $6.70 \pm 0.33$ & $6.62 \pm 0.31$ & $6.49 \pm 0.27$ & $6.66 \pm 0.23$ & $6.46 \pm 0.24$ & $6.51 \pm 0.19$ \\
\hline Overrun, \% & $48.9 \pm 2.83$ & $48.8 \pm 2.53$ & $50.3 \pm 3.09$ & $50.0 \pm 2.23$ & $49.1 \pm 2.62$ & $50.4 \pm 2.46$ \\
\hline
\end{tabular}

${ }^{1} \mathrm{CON}=$ control diet; $\mathrm{PAL}=$ diet with palm oil; $\mathrm{COC}=$ diet with coconut fat. 
Table 4. Ice cream microbial results

\begin{tabular}{lccc}
\hline Diet $^{1}$ & $\begin{array}{c}\text { Thermotolerant } \\
\text { coliforms, cfu/g }\end{array}$ & $\begin{array}{c}\text { Coagulase-positive } \\
\text { Staphylococcus spp., cfu/g }\end{array}$ & $\begin{array}{c}\text { Salmonella } \\
\text { spp., } / 25 \mathrm{~g}\end{array}$ \\
\hline CON & $3 \times 10^{1}$ & $<1.0 \times 10^{2}$ & Absent \\
PAL & $<1.0 \times 10^{1}$ & $<1.0 \times 10^{2}$ & Absent \\
COC & $<1.0 \times 10^{1}$ & $<1.0 \times 10^{2}$ & Absent \\
RDC $\mathrm{n}^{\circ}$ 12 ANVISA & $1 \times 10^{3}$ & $1 \times 10^{3}$ & Absent \\
\hline
\end{tabular}

${ }^{1} \mathrm{CON}=$ control diet; PAL $=$ diet with palm oil; $\mathrm{COC}=$ diet with coconut fat; $\mathrm{RDC} \mathrm{n}^{\mathrm{0}} 12$ ANVISA $=$ Brazilian legislation (regulatory limit for bacteria in ice cream) of the Agência Nacional de Vigilância Sanitária (ANVISA, 2001).

presented. We observed that during the first period, $\mathrm{L}^{*}$ was higher for PAL. During the second period, $\mathrm{L}^{*}$ was lower for CON, which demonstrates the capacity to reflect a great part of the light.

The variance analysis for the $a^{*}$ parameter revealed that CON was higher in the first period. During the second period, no significant difference existed for the ice cream produced. Regarding $b^{*}$, no significant difference in ice cream samples was detected for the 3 treatments in both production periods, with a tendency to a positive yellow color.

In a previous study, Sagdic et al. (2011) evaluated probiotic ice cream and found values for color analysis of almost 60.03 for $\mathrm{L}^{*}, 1.58$ for $\mathrm{a}^{*}$, and 16.75 for $\mathrm{b}^{*}$, which are similar to the ones found in the current study. For $\mathrm{C}^{*}$ and $\mathrm{H}^{*}$ parameters, no significant difference existed in ice cream samples for the 3 treatments in both production periods, showing no variation for tonality in ice cream samples. Karaman et al. (2014) incorporated persimmon purees into ice cream and observed that this incorporation caused a significant change in the color of the final ice cream products $(P<0.05)$. The $\mathrm{L}^{*}$ values found were about 50.56 and 70.11 , which are similar to the ones found in the current study (55.1 to $66.2)$.

When analyzing the ice cream texture, no significant difference was found for the samples evaluated (Table
6). Texture was measured as the peak strength necessary to shear the sample. This indicates the product structural rigidity; thus, the firmer the sample, the greater the strength necessary to shear it. In a similar study, Silva and Bolini (2006) evaluated ice cream texture and found a product with similar characteristics, with a rigidity of $269 \mathrm{kgf}$ (for the standard sample without milk replacement by whey).

\section{Consumer Test}

According to the data shown in Table 6, all treatments obtained scores among "slightly liked it" and "highly liked it," indicating good acceptance from tasters (acceptability index $\geq 70 \%$ ). Several authors studied the sensory acceptability of ice cream: Ferraz et al. (2012) developed a probiotic ice cream with different overrun levels and found scores for smell between 6.83 and $7.55,7.23$ and 7.68 for taste, and 7.02 and 7.49 for texture, similar to those found in our study. Shaviklo et al. (2011) fortified ice cream with fish protein and found that a concentration of 5 and $30 \mathrm{~g}$ of protein/ $\mathrm{kg}$ did not influence sensorial attributes evaluated and also increased protein levels in ice cream.

Silva and Bolini (2006) evaluated the sensorial analysis of ice cream produced with different concentrations of whey. The products formulated with the replacement

Table 5. Results from ice cream colorimetric and texture analysis (mean \pm SD from analyses in triplicate)

\begin{tabular}{|c|c|c|c|c|c|c|}
\hline \multirow[b]{2}{*}{ Parameter $^{1}$} & \multicolumn{3}{|c|}{ Period 1 diet $^{2}$} & \multicolumn{3}{|c|}{ Period 2 diet $^{2}$} \\
\hline & $\mathrm{CON}$ & PAL & $\mathrm{COC}$ & $\mathrm{CON}$ & PAL & $\mathrm{COC}$ \\
\hline $\mathrm{L}^{*}$ & $57.7 \pm 1.27^{\mathrm{b}}$ & $64.5 \pm 2.72^{\mathrm{a}}$ & $55.1 \pm 3.09^{\mathrm{b}}$ & $58.9 \pm 3.28^{\mathrm{B}}$ & $62.7 \pm 2.28^{\mathrm{A}}$ & $66.2 \pm 2.09^{\mathrm{A}}$ \\
\hline$a^{*}$ & $2.51 \pm 0.51^{\mathrm{a}}$ & $1.50 \pm 0.24^{\mathrm{b}}$ & $1.61 \pm 0.29^{\mathrm{b}}$ & $1.99 \pm 0.54$ & $2.00 \pm 0.30$ & $2.45 \pm 0.99$ \\
\hline$b^{*}$ & $25.2 \pm 2.29$ & $25.3 \pm 1.46$ & $25.2 \pm 1.59$ & $23.7 \pm 1.36$ & $23.4 \pm 1.86$ & $25.45 \pm 1.84$ \\
\hline $\mathrm{C}^{*}$ & $25.2 \pm 2.37$ & $25.3 \pm 1.46$ & $25.4 \pm 1.59$ & $23.9 \pm 1.36$ & $23.4 \pm 7.37$ & $25.7 \pm 1.73$ \\
\hline $\mathrm{H}^{*}$ & $86.3 \pm 2.68$ & $87.2 \pm 1.54$ & $87.1 \pm 1.72$ & $86.6 \pm 1.80$ & $86.4 \pm 1.64$ & $85.0 \pm 2.26$ \\
\hline Texture (rigidity), kgf & $530 \pm 241$ & $471 \pm 149$ & $350 \pm 96.9$ & $440.9 \pm 76.6$ & $400 \pm 109$ & $488 \pm 275$ \\
\hline
\end{tabular}

\footnotetext{
$\overline{\mathrm{a}, \mathrm{b}}$ Means within a row followed by different superscript lowercase letters are different within period 1 by Bonferroni test at $5 \%$ probability.

${ }^{\mathrm{A}, \mathrm{B}}$ Means within a row followed by different superscript uppercase letters are different within period 2 by Bonferroni test at $5 \%$ probability. ${ }^{1} \mathrm{~L}^{*}=$ luminosity on a scale from 0 (black) to 100 (white); $\mathrm{a}^{*}=$ a tone scale varying from red (positive values) to green (negative values); $\mathrm{b}^{*}=$ scale from yellow (positive values) to blue (negative values); $\mathrm{C}^{*}=$ color saturation rate (nondimensional); $\mathrm{H}^{*}=$ tone angle (nondimensional). ${ }^{2} \mathrm{CON}=$ control diet; $\mathrm{PAL}=$ diet with palm oil; $\mathrm{COC}=$ diet with coconut fat.
} 
Table 6. Results (mean $\pm \mathrm{SD}$ ) from ice cream sensorial analysis

\begin{tabular}{lccc}
\hline & \multicolumn{3}{c}{ Diet $^{2}$} \\
\cline { 2 - 4 } Sensorial characteristic $^{1}$ & CON & PAL & COC \\
\hline Smell & $6.72 \pm 1.31$ & $6.50 \pm 1.52$ & $6.74 \pm 1.38$ \\
Taste & $7.36 \pm 1.37^{\mathrm{a}}$ & $6.78 \pm 1.67^{\mathrm{b}}$ & $7.56 \pm 1.30^{\mathrm{a}}$ \\
Color & $6.98 \pm 1.20$ & $7.12 \pm 1.38$ & $7.56 \pm 1.28$ \\
Texture (rigidity) & 81.78 & $6.59 \pm 1.67$ & $7.33 \pm 1.30$ \\
Acceptability index, \% & 75.33 & 84 \\
${ }^{\mathrm{a}, \mathrm{b}}$ Means within a row followed by different superscript letters are significantly different by the Bonferroni test \\
at the 5\% probability level. & & \\
${ }^{1}$ The acceptance test was applied using a 9-point hedonic scale, from 1 = highly disliked it to 9 $=$ highly liked \\
it (Pimentel et al., 2013; Morais et al., 2014). \\
${ }^{2}$ CON = control diet; PAL = diet with palm oil; COC = diet with coconut fat.
\end{tabular}

of skim milk powder by $30 \%$ dry acid whey product, $100 \%$ demineralized whey, or 100\% CPS-35 (35\% whey protein concentrate), had as much sensorial acceptance as the formulated pattern with only skim milk powder.

In this context, ice cream should be considered not as a mere delicacy or summer pleasure, but a valuable and nutritive dessert that contributes with highly relevant elements to a balanced diet both for children and adults. It is a product enjoyed by people of all ages.

\section{Ice Cream Chromatographic Analysis}

For ice cream, the major FA composition (Table 7) was palmitic (16:0), vaccenic (18:1n-7), stearic (18:0), myristic (14:0), and lauric (12:0). Fatty acids identified were elaidic acid (trans 18:1-9) and CLA (cis-9,trans-11 C18:2).

Chiara et al. (2003) analyzed FA in ice cream consumed in Brazilian found a similar FA composition from the present work. The authors state that fat from both animal and vegetal origin are constituted by saturated and unsaturated FA (mono- and polyunsaturated). Oils and fat are essential components to a human diet once they perform different roles in human organism such as energetic reserve, phospholipids source, essential sterols and FA, and also assist the transport and absorption of fat-soluble vitamins, and still makes food more tasteful.

Table 7. Results from ice cream chromatographic analysis (\% relative area; mean \pm SD from analyses in triplicate)

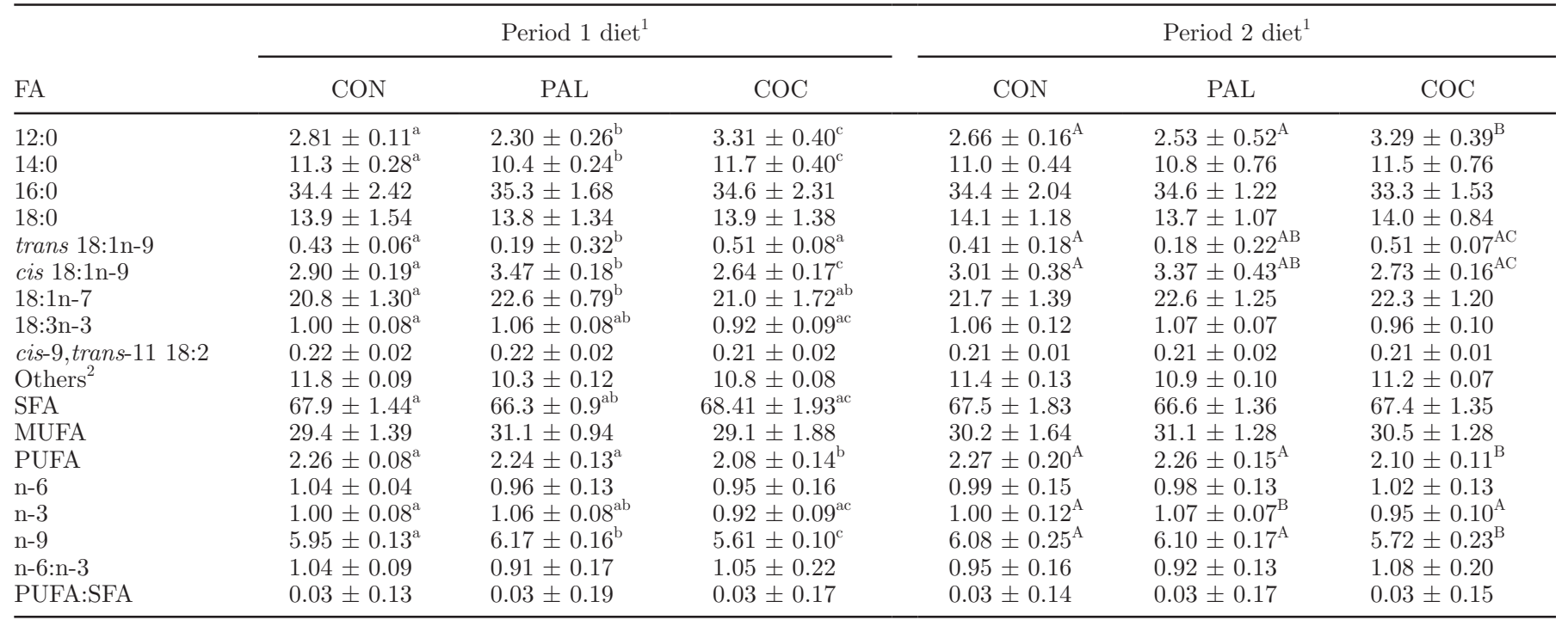

${ }^{\mathrm{a}-\mathrm{c}}$ Means within a row followed by different superscript lowercase letters within period 1 are significantly different by the Bonferroni test at the $5 \%$ probability level.

${ }^{\mathrm{A}-\mathrm{C}}$ Means within a row followed by different superscript uppercase letters within period 2 are significantly different by the Bonferroni test at the $5 \%$ probability level.

${ }^{1} \mathrm{CON}=$ control diet; $\mathrm{PAL}=$ diet with palm oil; $\mathrm{COC}=$ diet with coconut fat.

${ }^{2} 4: 0,6: 0,8: 0,10: 0,14: 1 \mathrm{n}-11,14: 1 \mathrm{n}-9,14: 1 \mathrm{n}-7,15: 0,15: 1 \mathrm{n}-9,16: 1 \mathrm{n}-11,16: 1 \mathrm{n}-9,16: 1 \mathrm{n}-7$, iso 17:0, 17:0, 17:1n-9, trans 18:2n-6, and cis 18:2n-6. 
The difference among trans FA from lactic fat and those from hydrogenated fat is not related only to quantity but also to the sort of predominant isomers in one or the other. Among trans FA resulting from the biohydrogenation process, vaccenic acid is predominant, whereas elaidic acid prevails in fat that undergoes hydrogenation. Elaidic acid is considered to be the main competitor of linoleic acid in human metabolism, especially when the ingestion of linoleic acid is reduced (Chiara et al., 2003).

When comparing FA composition of milk and ice cream, it can be observed that treatment with COC, even as for milk characterization, presented high lauric acid (12:0) concentration in ice cream in both periods. And the PAL, which has high oleic acid (cis 18:1n-9) content, increased this FA in milk and in the ice cream. Comparing the milk FA profile with the ice cream, we observed that SFA concentration, in both, was higher in the CON treatment and lower in the PAL and COC treatments; PUFA concentration was higher in PAL and lower in CON and COC treatments; MUFA concentration in milk was higher in the PAL and COC treatments and lower in CON, but when we analyzed the ice cream no differences were found.

In the case of n-3, we know that its daily ingestion is recommended (Simionato et al., 2010). When comparing n-3 content in milk and ice cream, we observed that PAL had higher levels than CON and COC. No significant difference was found in some FA and components (fat). Because the concentration of PAL and COC was $10 \%$, the concentration of PAL or COC in the diets could be a lower value; however, other concentrations could be evaluated in future studies.

\section{CONCLUSIONS}

Comparing the milk FA profile with that of ice cream, we observed that treatment with COC, even as for milk characterization, presented high lauric acid (12:0) concentration in ice cream in both periods, and treatment with PAL increased the oleic acid (cis 18:1n-9) content in milk and ice cream. Saturated FA concentration, in both products, was higher in the CON treatment and lower in the PAL and COC treatments; PUFA concentration was higher in the PAL and lower in the CON and COC treatments; MUFA concentration for milk was higher in PAL and COC treatments and lower in $\mathrm{CON}$, but when we analyzed the ice cream, no differences were found. When comparing n-3 content in milk and ice cream, we observed that PAL had higher levels than CON and COC. Thus, it was possible to develop ice creams with excellent sensorial characteristics presenting great acceptability regarding evaluated attributes. The physicochemical and sensorial analyses of the products proved that it is possible to conduct animal feeding supplementation without causing alterations in the final product (ice cream). According to our results, feeding dairy cows different types of fat (PAL and COC) to obtain milk and, consequently, goodquality dairy products is possible. The dairy industry can use principally PAL to improve the ice cream FA profile; however, it is important to optimize the oil concentration to obtain significant improvements.

\section{ACKNOWLEDGMENTS}

The authors thank Coordenação de Aperfeiçoamento de Pessoal de Nível Superior (CAPES, Brasília, Brazil) for encouragement to develop research in Brazil.

\section{REFERENCES}

ANVISA (Agência Nacional de Vigilância Sanitária). 1999. Portaria $\mathrm{n}^{\circ}$ 379, de 26 de abril de 1999. Regulamento Técnico referente a Gelados Comestíveis, Preparados, Pós para o Preparo e Bases para Gelados Comestíveis. Brasília: Diário Oficial da União. Accessed Feb. 15, 2014. http://portal.anvisa.gov.br/wps/wcm/connect/ e824d8804a9bdce99854dc4600696f00/Portaria_n_379_de_26_de_ abril_de_1999.pdf?MOD=AJPERES.

ANVISA (Agência Nacional de Vigilância Sanitária). 2001. Resolução RDC $\mathrm{n}^{\mathrm{Q}} 12$, de 2 de janeiro de 2001. Regulamento Técnico sobre Padrões Microbiológicos para Alimentos. Brasília: Diário Oficial da União. Accessed Feb. 20, 2014. http://portal.anvisa. gov.br/wps/wcm/connect/a47bab8047458b909541d53fbc4c6735/ RDC_12_2001.pdf?MOD=AJPERES.

AOAC International. 1998. Official Methods of Analysis. AOAC International, Arlington, VA.

Arbonés-Mainar, J. M., M. Navarro, S. Acín, M. A. Guzmán, C. Arnal, J. C. Surra, R. Carnicer, H. M. Roche, and J. Osada. 2006. Trans-10, cis-12- and cis-9, trans-11-conjugated linoleic acid isomers selectively modify HDL-apolipoprotein composition in apolipoprotein E knockout mice. J. Nutr. 136:353-359.

Bligh, E. G., and W. J. Dyer. 1959. A rapid method of total lipid extraction and purification. Can. J. Biochem. Physiol. 37:911-917.

Cadena, R. S., A. G. Cruz, J. A. F. Faria, and H. M. A. Bolini. 2012. Reduced fat and sugar vanilla ice creams: Sensory profiling and external preference mapping. J. Dairy Sci. 95:4842-4850. http:// dx.doi.org/10.3168/jds.2012-5526.

Caroprese, M., M. Albenzio, R. Marino, A. Santillo, and A. Sevi. 2013. Dietary glutamine enhances immune responses of dairy cows under high ambient temperature. J. Dairy Sci. 96:3002-3011. http:// dx.doi.org/10.3168/jds.2012-6306.

Chen, S., G. Bobe, S. Zimmerman, E. G. Hammond, C. M. Luhman, T. D. Boylston, A. E. Freeman, and D. C. Beitz. 2004. Physical and sensory properties of dairy products from cows with various milk fatty acid compositions. J. Agric. Food Chem. 52:3422-3428.

Chiara, V. L., R. Sichieri, and T. S. F. Carvalho. 2003. Teores de ácidos graxos trans de alguns alimentos consumidos no Rio de Janeiro. Revista de Nutrição 16:227-233.

Corradini, S. A. S., G. S. Madrona, N. E. Souza, I. N. Prado, E. G. Bonafe, C. B. Carvalho, and I. N. Prado. 2013. Sensorial characteristics and fatty acid Mozzarella cheese from milk of crossbred cows fed with palm oil and coconut fat. Acta Sci. Technol. 35:789-795. http://dx.doi.org/10.4025/actascitechnol.v35i4.20158.

Di Criscio, T., A. Fratianni, R. Mignogna, L. Cinquanta, R. Coppola, E. Sorrentino, and G. Panfili. 2010. Production of functional probiotic, prebiotic, and synbiotic ice creams. J. Dairy Sci. 93:45554564. http://dx.doi.org/10.3168/jds.2010-3355.

Ferraz, J. L., A. G. Cruz, R. S. Cadena, M. Q. Freitas, U. M. Pinto, C. C. Carvalho, J. A. F. Faria, and H. M. A. Bolini. 2012. Sensory ac- 
ceptance and survival of probiotic bacteria in ice cream produced with different overrun levels. J. Food Sci. 77:S24-S28. http:// dx.doi.org/10.1111/j.1750-3841.2011.02508.x.

Fonseca, L. F. L. 2000. Qualidade do leite e controle de mastite. Lemos Editorial, São Paulo, SP, Brazil.

Funck, L. G., D. Barrera-Arellano, and J. M. Block. 2006. Ácido linoléico conjugado (CLA) e sua relação com a doença cardiovascular e os fatores de risco associados. Archivos Latinoamericanos de Nutrición 56:123-134.

Goff, H. D. 2002. Formation and stabilisation of structure in ice-cream and related products. Curr. Opin. Coll. Interface Sci. 7:432-437. http://dx.doi.org/10.1016/S1359-0294(02)00076-6.

Harwood, M. L., J. R. Loquasto, R. F. Roberts, G. R. Ziegler, and J. E. Hayes. 2013. Explaining tolerance for bitterness in chocolate ice cream using solid chocolate preferences. J. Dairy Sci. 96:49384944. http://dx.doi.org/10.3168/jds.2013-6715.

ISO (International Organization for Standardization). 1978. Animal and vegetable fats and oils - Preparation of methyl esters of fatty acids. Method ISO 5509. ISO, Geneva, Switzerland.

Karaca, O. B., M. Güven, K. Yasar, S. Kaya, and T. Kahyaoglu. 2009. The functional, rheological and sensory characteristics of ice creams with various fat replacers. Int. J. Dairy Technol. 62:93-99. http://dx.doi.org/10.1111/j.1471-0307.2008.00456.x.

Karaman, S., Ö. S. Toker, F. Yüksel, M. Çam, A. Kayacier, and M. Dogan. 2014. Physicochemical, bioactive, and sensory properties of persimmon-based ice cream: Technique for order preference by similarity to ideal solution to determine optimum concentration. J. Dairy Sci. 97:97-110. http://dx.doi.org/10.3168/jds.2013-7111.

Machado, G. C., J. B. P. Chaves, and R. Antoniassi. 2006. Composição em ácidos graxos e caracterização física e química de óleos hidrogenados de coco babaçu. Rev. Cer. 53:463-470.

Machado, P. F., A. R. Pereira, L. F. P. Silva, and G. A. Sarriés. 2000. Células somáticas no leite em rebanhos brasileiros. Scientia Agricola 57:359-361.

MAPA (Ministério da Agricultura, Pecuária e Abastecimento). 2011. Instrução Normativa nº 62 de 31/12/2011. MAPA, Brasília, Brazil.

Marshall, R. T., H. D. Goff, and R. W. Hartel. 2003. Ice Cream. Plenum Publisher, New York, NY.

Meilgaard, M., G. Civille, and B. T. Carr. 1991. Sensory Evaluation Techniques. CRC Press, Boca Raton, FL.

Morais, E. C., A. G. Cruz, and H. M. A. Bolini. 2014. Development of chocolate dairy dessert with addition of prebiotics and replacement of sucrose with different high-intensity sweeteners. J. Dairy Sci. 97:2600-2609. http://dx.doi.org/10.3168/jds.2013-7603.
Nozière, P., B. Graulet, A. Lucas, B. Martin, P. Grolier, and M. Doreau. 2006. Carotenoids for ruminants: From forages to dairy products. Anim. Feed Sci. Technol. 131:418-450. http://dx.doi. org/10.1016/j.anifeedsci.2006.06.018

Pereira, G. G., J. V. Resende, L. R. Abreu, T. M. O. Giarola, and I. T. Perrone. 2011. Influence of the partial substitution of skim milk powder for soy extract on ice cream structure and quality. Eur. Food Res. Technol. 232:1093-1102. http://dx.doi.org/10.1007/ s00217-011-1483-z.

Pimentel, T. C., A. G. Cruz, and S. H. Prudencio. 2013. Short communication: Influence of long-chain inulin and Lactobacillus paracasei subspecies paracasei on the sensory profile and acceptance of a traditional yogurt. J. Dairy Sci. 96:6233-6241. http://dx.doi. org/10.3168/jds.2013-6695.

Sagdic, O., I. Ozturk, H. Cankurt, and F. Tornuk. 2011. Interaction between some phenolic compounds and probiotic bacterium in functional ice cream production. Food Bioproc. Technol. 5:29642971. http://dx.doi.org/10.1007/s11947-011-0611-x.

Shaviklo, G. R., G. Thorkelsson, K. Sveinsdottir, and F. Rafipour. 2011. Chemical properties and sensory quality of ice cream fortified with fish protein. J. Sci. Food Agric. 91:1199-1204. http:// dx.doi.org/10.1002/jsfa.4299.

Silva, K., and H. M. A. Bolini. 2006. Avaliação sensorial de sorvete formulado com produto de soro ácido de leite bovino. Ciênc. Tecnol. Aliment. 26:116-122.

Silva Junior, E., and S. C. S. Lannes. 2011. Effect of different sweetener blends and fat types on ice cream properties. Ciênc. Tecnol. Aliment. 31:217-220. http://dx.doi.org/10.1590/S010120612011000100033.

Simionato, J. I., J. C. Garcia, G. T. Santos, C. C. Oliveira, J. V. Visentainer, and N. E. Souza. 2010. Validation of the determination of fatty acids in milk by gas chromatography. J. Braz. Chem. Soc. 21:520-524. http://dx.doi.org/10.1590/S0103-50532010000300018.

Sousa, P. H. M., G. A. Maia, M. S. M Souza Filho, R. W. Figueiredo, and A. C. R. Souza. 2003. Goiabas desidratadas osmoticamente seguidas de secagem em estufa. Rev. Bras. Frutic. 25:414-416.

Stone, H., and J. L. Sidel. 1985. Affective testing. Chapter 7 in Sensory Evaluation Practices. Academic Press, Boca Raton, FL.

Warke, R., A. Kamat, M. Kamat, and P. Thomas. 2000. Incidence of pathogenic psychrotrophs in ice creams sold in some retail outlets in Mumbai, India. Food Contr. 11:77-83. http://dx.doi. org/10.1016/S0956-7135(99)00027-4. 